\title{
PENERAPAN PRINSIP RESTORATIVE JUSTICE DALAM PENYELESAIAN TINDAK PIDANA KEKERASAN SEKSUAL YANG DILAKUKAN OLEH PELAKU ANAK (Studi di Wilayah Hukum Polres Banjarnegara dan Polres Purbalingga) Septi Pusporini ${ }^{1}$
}

\begin{abstract}
The crime of sexual violence perpetrators and victims are children. the handling of criminal acts against sexual violence, attempted a settlement other than through criminal justice so that the need to look for solutions. The solution is expected to be used as a model of a settlement which can protect the interests or rights of the child.

The implementation of restorative justice principle in accomplishing the criminal act of sexual abuse and the obstacles that were faced in implementing the restorative justice principle to accomplish the criminal act of sexual abuse that was conducted by children actors. This research used sociolo legal approach. The source of data involved primary data and secondary data which the collection method of its data was conducted by interview, observation, and literature study and presented by using the narrative text form and then analyzed qualitatively.

The application of the principles of restorative justice in Polres Banjarnegara and at Polres Purbalingga through the peace process, the termination of the investigation has been achieved because of the deal, giving aid of school costs, child abusers don't hold, keep doing your assignment the suspect, considering certain aspects for mediation, marrying the victim with the offender, stress damages the legal process, but still protect the child, the completion of the matter in mediation of the indigenous family.

Barriers experienced with regard to the formulation of law or a question of substance, or institutional structure, and the question of the culture or cultures that live and thrive in society. These obstacles include the number of polwan that are still very minimal understanding of the gender that has not been adequate, a lack of understanding of the law plus does not know the rules about sexual violence committed by the child, understanding the principle of restorative justice have not depth, the various regulations concerning children still overlap, yet the existence of a norm which guarantees the Equality Act, the application of restorative justice is considered not making the perpetrator deterrent and it is possible to repeat theAct, not all cases can be completed with restorative justice because there is a supposed wrong should be punished.
\end{abstract}

\section{Keywords: restorative justice, criminal act of sexual abuse, children actors}

\begin{abstract}
Abstrak
Tindak pidana kekerasan seksual pelaku dan korbannya adalah anak. penanganan tindak pidana kekerasan seksual terhadap anak, diupayakan suatu penyelesaian selain melalui peradilan pidana sehingga perlu dicarikan solusi. Solusi tersebut diharapkan dapat digunakan sebagai model penyelesaian yang dapat melindungi kepentingan maupun hak-hak anak.

Penerapan prinsip restorative justice dalam penyelesaian tindak pidana kekerasan seksual yang dilakukan oleh pelaku anak dan untuk menganalisa hambatanhambatan yang dihadapi. Metode pendekatan yuridis sosiologis dengan tipe penelitian hukum sosiologis, dan sumber data meliputi sumber data primer dan data sekunder, dan dianalisis secara kualitatif.

Penerapan prinsip restorative justice di Polres Banjarnegara dan di Polres Purbalingga melalui proses perdamaian, penghentian penyidikan karena dicapainya kesepakatan, memberi bantuan biaya sekolah, tidak menahan pelaku anak, tetap melakukan penetapan tersangka, mempertimbangkan aspek tertentu untuk mediasi, menikahkan korban dengan pelaku, menitikberatkan ganti rugi, melakukan proses hukum namun tetap melindungi anak, penyelesaian perkara secara mediasi adat kekeluargaan.
\end{abstract} Magister Hukum Fakultas Hukum Universitas Jenderal Soedirman, Email:
septipusporini@gmail.com 
657 | Jurnal Idea Hukum

Vol. 3 No. 2 Oktober 2017

Magister Hukum Fakultas Hukum Universitas Jenderal Soedirman

Hambatan yang dialami berkaitan dengan rumusan hukum atau substansi, persoalan kelembagaan atau strukturnya, dan persoalan kultur atau budaya yang hidup dan berkembang di dalam masyarakat. Hambatan tersebut antara lain jumlah polwan yang masih sangat minim, pemahaman gender yang belum memadai, kurangnya pemahaman hukum ditambah tidak tahu aturan tentang kekerasan seksual yang dilakukan oleh anak, pemahaman prinsip restorative justice belum mendalam, berbagai peraturan tentang anak masih tumpang tindih, belum adanya norma yang menjamin kesamaan tindakan, penerapan restorative justice dianggap tidak membuat pelaku jera dan dimungkinkan mengulangi perbuatan, belum semua kasus dapat diselesaikan dengan restorative justice karena ada anggapan orang salah harus dihukum.

Kata kunci: restorative justice, tindak pidana kekerasan seksual, pelaku anak

\section{PENDAHULUAN}

Terdapat tindak pidana

kekerasan seksual yang pelaku dan korbannya adalah anak. Terhadap korban, dibutuhkan suatu perlindungan hukum, oleh karena itu, diperlukan alternatif cara penyelesaian selain peradilan pidana. Hal tersebut sesuai dengan tujuan penyelenggaraan tujuan sistem peradilan pidana anak bahwa perkara anak wajib diselesaikan melalui jalur di luar pengadilan sehingga diupayakan suatu penyelesaian melalui jalur non formal. Dalam penanganan tindak pidana kekerasan seksual terhadap anak, diupayakan suatu penyelesaian selain melalui peradilan pidana sehingga perlu dicarikan solusi. Solusi tersebut diharapkan dapat digunakan sebagai model penyelesaian yang dapat melindungi kepentingan maupun hak-hak anak.

Kekerasan terhadap anak adalah setiap perbuatan terhadap anak yang menimbulkan penderitaan secara fisik, seksual, psikologis dan penelantaran anak termasuk ancaman melakukan pemaksaan atau perampasan kemerdekaan secara hukum. Pengertian kekerasan seksual secara yuridis terdapat dalam Undangundang Nomor 23 Tahun 2004 tentang Penghapusan Kekerasan dalam Rumah Tangga yaitu pemaksaan hubungan seksual yang dilakukan terhadap orang lain dengan tujuan tertentu yang biasanya menunjukan aktivitas seksual yang diikuti penyerangan kepada korban. Apabila menimbulkan cedera fisik terhadap korban maka termasuk dalam kategori kekerasan seksual dengan penyerangan, dan apabila tidak ada cedera fisik termasuk kategori kekerasan seksual tanpa penyerangan, namun kekerasan seksual tanpa penyerangan tetap dapat menimbulkan trauma emosional terhadap korban.

Masalah anak merupakan masalah yang berhubungan dengan lingkungan rumah tangga. Undangundang Nomor 35 Tahun 2014 tentang Perubahan atas Undang-undang Nomor 23 Tahun 2002 tentang Perlindungan Anak tidak memberikan penjelasan bentuk-bentuk kekerasan terhadap anak, akan tetapi Undang-Undang Nomor 23 Tahun 2004 tentang Penghapusan Kekerasan dalam Rumah 
Tangga menyatakan bentuk-bentuk kekerasan yaitu kekerasan fisik, kekerasan emosional atau psikis, kekerasan seksual, dan penelantaran rumah tangga. Di Indonesia terdapat beberapa undang-undang yang mengatur mengenai kejahatan seksual, serta terdapat beberapa ketentuan dalam KUHP yang menyangkut kekerasan seksual yaitu yang diatur dalam BAB XIV tentang Kejahatan Terhadap Kesusilaan dan terdapat pula dalam beberapa undang-undang lainnya. Bentuk-bentuk kejahatan seksual terhadap anak dalam prespektif hukum antara lain Tindak Pidana Perkosaan, Tindak Pidana Pencabulan atau Pelecehan Seksual, dan Tindak Pidana Eksploitasi Seksual.

Kekerasan seksual menimbulkan banyak akibat negatif apalagi jika korbannya adalah anak yang masih membutuhkan waktu untuk tumbuh dan berkembang. Tindak kekerasan tersebut pasti akan sangat membekas dan meninggalkan efek yang lama baik secara fisik maupun secara mental. Bentuk-bentuk kekerasan seksual umumnya dilakukan dengan upaya memaksa dan keinginan salah satu pihak saja untuk merayu, mencolek, memeluk, meremas bagian tubuh, dan segala macam bentuk pelecehan lainnya hingga tujuan utamanya melakukan persetubuhan secara paksa. Kekerasan seksual dapat terjadi karena beberapa hal, mulai dari pola pengasuhan keluarga yang keliru, penyebaran pornografi di sosial media yang tidak terkontrol, hingga tidak adanya pendidikan seksual yang benar sejak dini. Hal tersebut membuat anak tidak mampu menyaring informasi yang seharusnya didapat sehingga anak cenderung berbuat salah. Berdasarkan hal tersebut, maka diperlukan pengawasan dan bimbingan dari orang tua untuk mengarahkan anak agar mampu membedakan hal yang positif dan bermanfaat serta menjauhi hal negatif yang berbahaya.

Memberikan hukuman kepada pelaku bukan merupakan alternatif yang baik dalam memperbaiki kepribadian pelaku, sedangkan korban juga membutuhkan orang yang bertanggung jawab terhadap masa depan dan kehidupannya. Model kebijakan aparat yang menyerahkan penyelesaian masalah kepada orang tua pelaku dan orang tua korban merupakan suatu penyelesaian yang beraspek restorative justice. Penyelesaian perkara pada umumnya merupakan penerapan ganti rugi oleh pelaku dan keluarganya kepada korban atau keluarganya untuk menghindari konsekuensi balas dendam. Restorative justice mempunyai cara berfikir dan paradigma baru dalam memandang sebuah tindak kejahatan yang dilakukan oleh seorang manusia tanpa semata-mata memberikan hukuman pidana. Menurut pandangan konsep restorative justice penanganan kejahatan yang terjadi bukan hanya menjadi tanggung jawab negara akan tetapi juga merupakan tanggung jawab masyarakat. Oleh karena itu konsep 
659 | Jurnal Idea Hukum

Vol. 3 No. 2 Oktober 2017

Magister Hukum Fakultas Hukum Universitas Jenderal Soedirman

restorative justice dibangun berdasarkan pengertian bahwa kejahatan yang telah menimbulkan kerugian harus dipulihkan kembali baik kerugian yang diderita oleh korban maupun kerugian yang ditanggung oleh masyarakat. ${ }^{2}$

Tujuan penyelenggaraan

sistem peradilan terhadap anak dinyatakan dalam Undang-undang Nomor 11 Tahun 2012 tentang Sistem Peradilan Pidana Anak yang memberikan penyelesaian melalui jalur non formal terhadap tahapan proses hukum yaitu dengan menggunakan pendekatan restorative justice. Pasal 5 ayat (1) Undang-undang Nomor 11 Tahun 2012 tentang Sistem Peradilan Pidana Anak menyatakan bahwa Sistem Peradilan Pidana Anak wajib mengutamakan pendekatan keadilan restoratif. Selanjutnya Pasal 1 butir (6) Undang-undang Nomor 11 Tahun 2012 tentang Sistem Peradilan Pidana Anak menyatakan bahwa keadilan restoratif adalah penyelesaian perkara tindak pidana dengan melibatkan pelaku, korban, keluarga pelaku/korban, dan pihak lain yang terkait untuk mencari penyelesaian yang adil dengan menekankan pemulihan kembali pada keadaan semula dan bukan pada pembalasan. Penerapan prinsip restorative justice merupakan upaya penyelesaian tindak pidana yang dilakukan oleh anak. Undang-undang

2 Marlina, 2010, Pengantar Konsep Diversi dan Restorative Justice dalam Hukum Pidana, Medan: USU Press, hlm. 38-40.
Nomor 11 Tahun 2012 tentang Sistem

Peradilan Pidana Anak telah mengutamakan pendekatan restorative justice sebagai upaya untuk penyelesaian tindak pidana yang dilakukan oleh anak. Sistem peradilan pidana bagi anak tentunya memiliki tujuan khusus terhadap kepentingan masa depan anak dan masyarakat seperti yang terkandung dalam prinsip restorative justice.

Melihat uraian tersebut, terdapat pola-pola penyelesaian yang terintegrasi yaitu dengan adanya anak korban tindak pidana kekerasan seksual yang dilakukan oleh pelaku anak, maka upaya penyelesaian dengan penerapan restorative justice diharapkan akan dapat mengembalikan pelaku kepada orang tua setelah ada penyelesaian masalah dengan korban. Penerapan restorative justice sangat berkaitan terhadap tindak pidana kekerasan seksual pada anak karena kerugian korban tetap tidak dapat dikembalikan. Adanya pola penyelesaian yang saling terkait tersebut, penulis ingin mengkaji penyelesaian penanganan tindak pidana anak dengan penerapan prinsip restorative justice dalam penyelesaian tindak pidana kekerasan seksual yang dilakukan oleh pelaku anak di Kepolisian Resort Banjarnegara dan di Kepolisian Resort Purbalingga. Pemilihan lokasi penelitian berdasarkan pertimbangan bahwa Banjarnegara dan Purbalingga memiliki latar belakang budaya serta perilaku masyarakat yang menarik misalnya gaya hidup para pelajar pada 
segmen tertentu yang memungkinkan terjadinya tindak pidana kekerasan seksual.

Angka kekerasan seksual di Banjarnegara cenderung mengalami kenaikan yang patut diwaspadai. Tahun 2009 tercatat ada 27 kasus kekerasan dan 11 diantaranya adalah kejerasan seksual dengan korban perempuan dewasa 4 orang dan 7 anak perempuan. Tahun 2010 mengalami kenaikan drastis, tercatat ada 62 kasus kekerasan dengan korban kekerasan seksual mencapai 23 orang, 1 perempuan dewasa 19 korban anak perempuan dan 3 anak laki-laki. Tahun 2011 pun demikian, tercatat 63 kasus kekerasan dengan korban kekerasan seksual berjumlah 12 orang, 1 perempuan dewasa dan 12 korban anak perempuan. Sedangkan pada tahun 2012 tercatat 61 kasus kekerasan dengan korban sebanyak 23 orang, 1 perempuan dewasa serta 22 anak perempuan. Tahun 2013 hanya tercatat 49 kekerasan dengan korban kekerasan seksual 22 orang, 2 perempuan dewasa, 3 anak laki-laki, dan 17 anak perempuan. $^{3}$

Tim penanganan korban tindak kekerasan terhadap perempuan dan anak, Harapan, Kabupaten Purbalingga, sejak tahun 2009 hingga Februari 2010 telah menangani 24 kasus tindak kekerasan terhadap perempuan dan

Wahyu Tanoto, Kekerasan Seksual di Banjarnegara,http://m.kompasiana.co $\mathrm{m} /$ cupiu7grafi/kekerasan-seksualdibanjarnegara, diakses pada tanggal 2 Desember 2015. anak. Jumlah kasus ini meliputi kasus Kekerasan dalam Rumah Tangga (KDRT), perkosaan anak, pencabulan, dan kekerasan dalam pacaran. Kasus terbanyak disebabkan karena faktor seksual (perkosaan dan pencabulan). Dari jumlah 24 kasus tersebut, sebanyak 19 kasus ditangani pada tahun 2009. Sementara sisanya sebanyak 5 kasus merupakan kasus sejak Januari hingga Februari 2010. Jika dibanding tahun 2008 lalu, jumlah kasus ini mengalami penurunan. Selama 2008 Tim Harapan telah menangani dan melakukan advokasi terhadap 23 kasus. ${ }^{4}$

Keaslian penulisan tesis ini dapat dibedakan dengan penelitian tesis terdahulu yang telah dilakukan oleh Bhineka Teruna Sari Putra pada tahun 2013 dengan judul tesis Penerapan Restorative Justice Dalam Penanganan Tindak Pidana Yang Dilakukan Oleh Anak (Studi di Wilayah Hukum Kepolisian Resort Purbalingga) yang pada dasarnya penelitian tersebut menitikberatkan kepada penanganan tindak pidana oleh anak dalam prespektif Restorative Justice yang dilakukan oleh Kepolisian Resort Purbalingga. Sedangkan dalam penulisan tesis ini lebih menitikberatkan kepada penerapan prinsip restorative justice terhadap tindak pidana

Banyumas1, Tim Harapan Purbalingga Tangani 24 Kasus KDRT, http://banyumasnews.com/9469/ timharapan purbalingga-tangani-24-kasuskdrt/, diakses pada tanggal 2 Desember 2015. 
661 | Jurnal Idea Hukum

Vol. 3 No. 2 Oktober 2017

Magister Hukum Fakultas Hukum Universitas Jenderal Soedirman

kekerasan seksual yang dilakukan oleh pelaku anak.

Selain itu, penulisan tesis ini juga dapat dibedakan dengan penelitian yang telah dilakukan oleh Ike Nurhayati Effendi pada tahun 2013 dengan judul tesis Penyelesaian Tindak Pidana Kekerasan Dalam Rumah Tangga Dengan Konsep Restorative Justice (Studi di Wilayah Hukum Polres Cilacap) yang pada dasarnya penelitian tersebut menitikberakan kepada penyelesaian kasus Kekerasan dalam Rumah Tangga (KDRT) dengan konsep Restorative Justice. Sehubungan dengan hal tersebut, dapat diketahui bahwa dalam penulisan tesis ini dapat dibedakan dengan penelitian tesis sebelumnya yang telah dilakukan oleh Bhineka Teruna Sari Putra dan oleh Ike Nurhayati Effendi.

\section{Berdasarkan hal-hal yang} diuraikan dalam latar belakang tersebut, penulis tertarik untuk melakukan penelitian yang menitikberatkan kepada penerapan prinsip restorative justice terhadap tindak pidana kekerasan seksual yang dilakukan oleh pelaku anak agar mendapat penyelesaian yang adil dengan menekankan pemulihan kembali pada keadaan semula dan bukan pada pembalasan. Penelitian tersebut berjudul: "PENERAPAN

PRINSIP RESTORATIVE JUSTICE

DALAM PENYELESAIAN TINDAK

PIDANA KEKERASAN SEKSUAL YANG DILAKUKAN OLEH PELAKU ANAK (Studi di Wilayah Hukum
Polres Banjarnegara dan Polres Purbalingga)".

\section{RUMUSAN MASALAH}

Berdasarkan uraian yang telah dikemukakan pada latar belakang di atas, maka dapat dirumuskan permasalahan sebagai berikut:

1. Bagaimana penerapan prinsip restorative justice dalam penyelesaian tindak pidana kekerasan seksual yang dilakukan oleh pelaku anak?

2. Hambatan-hambatan apa yang dihadapi dalam penerapan prinsip restorative justice untuk menyelesaikan tindak pidana kekerasan seksual yang dilakukan oleh pelaku anak?

\section{TUJUAN PENELITIAN}

Berdasarkan permasalahan yang telah diuraikan di atas, maka tujuan yang akan dicapai dalam penelitian ini adalah sebagai berikut:

1. Untuk menganalisa penerapan prinsip restorative justice dalam penyelesaian tindak pidana kekerasan seksual yang dilakukan oleh pelaku anak.

2. Untuk menganalisa hambatan-hambatan yang dihadapi dalam penerapan prinsip restorative justice untuk menyelesaikan tindak 
pidana kekerasan seksual yang dilakukan oleh pelaku anak.

\section{KEGUNAAN PENELITIAN}

\section{a. Secara Teoritis}

1. Memberikan sumbangan pemikiran bagi perkembangan ilmu hukum pada umumnya, serta menambah khasanah kepustakaan ilmu hukum khususnya hukum pidana;

2. Memberikan informasi yang lebih konkrit dalam usaha penerapan prinsip restorative justice dalam penyelesaian tindak pidana kekerasan seksual yang dilakukan oleh pelaku anak agar dapat selalu selaras dengan kemajuan ilmu pengetahuan.

b. Secara Praktis

1. Sebagai bahan pertimbangan bagi pihakpihak dan lembaga-lembaga yang terkait dalam rangka penerapan prinsip restorative justice sebagai bentuk penyelesaian tindak pidana kekerasan seksual yang dilakukan oleh pelaku anak;

2. Sebagai masukan bagi pemerintah maupun aparat penegak hukum dalam mengambil kebijakan terhadap penerapan prinsip restorative justice dalam penyelesaian tindak pidana kekerasan seksual yang dilakukan oleh pelaku anak.

\section{METODE PENELITIAN}

1. Metode PendekataN: Yuridis Sosiologis

2. Tipe Penelitian: Penelitian Hukum Sosiologis

3. Lokasi Penelitian: Wilayah Hukum Polres

Banjarnegara \& Purbalingga

1. Sumber Data: Sumber Data Primer dan Sumber Data Sekunder

2. Metode Pengumpulan Data: Wawancara, Observasi, dan Studi Pustaka

3. Metode Penyajian Data: Uraian yang disusun secara sistematis, logis, dan rasioanal

4. Analisis Data: Metode Kualitatif

\section{PEMBAHASAN}

1. Hasil Penelitian

a. Penerapan

Prinsip

Restorative Justice dalam Penyelesaian Tindak Pidana Kekerasan Seksual yang Dilakukan oleh Pelaku Anak

Data Primer

\begin{tabular}{lr}
\multicolumn{1}{c}{ Persepsi } & aparatur \\
Kepolisian Resort & (Polres) \\
Banjarnegara & terhadap \\
Restorative & Justice \\
dinyatakan bahwa: &
\end{tabular}


663 | Jurnal Idea Hukum

Vol. 3 No. 2 Oktober 2017

Magister Hukum Fakultas Hukum Universitas Jenderal Soedirman

"Restorative

Justice

merupakan prinsip yang kami

terapkan sebagai bentuk

perdamaian antara pelaku,

keluarga pelaku dengan

korban dan keluarga korban,

oleh karena itu menurut kami

Restorative Justice

merupakan suatu bentuk

penyelesaian dengan

perdamaian antara pelaku,

keluarga pelaku dengan

korban dan keluarga korban.

Bagi kami, Restorative

Justice adalah perdamaian

yang dilegakan. Meskipun

hukum pidana tidak

mengenal perdamaian,

namun Restorative Justice

kami terapkan karena kami

anggap lebih bermanfaat". 5

Sedangkan

persepsi aparatur Kepolisian

Resort (Polres) Purbalingga

terhadap Restorative Justice

dinyatakan bahwa:

"Menurut kami, Restorative Justice merupakan sistem perdamaian antara pihak yang melakukan tindak pidana dengan korban. Jadi, Restorative Justice adalah suatu sistem perdamaian para pihak. Sepemahaman

Hasil wawancara dengan Bripka Deberti Selfiana Doko, Penyidik Satuan Unit Perlindungan Perempuan dan Anak (PPA) Resort (Kepolisian Polres) Banjarnegara, pada hari Rabu tanggal 30 September 2015. kami, Restorative Justice

menjadi sarana pengobat derita korban bahwa tujuan pidana tidak hanya menghukum tetapi ya juga merehabilitasi korban". 6

Kepala Pusat

Pelayanan Terpadu

Perlindungan

Perempuan

dan Anak

(P2TP2A)

Kabupaten

Banjarnegara

menyatakan bahwa:

"Prinsip Restorative Justice bagi saya menjadi pilihan terhadap penyelesaian perkara yang melibatkan anak karena menurut saya penyelesaian perkara dalam Restorative Justice melibatkan orang tua pelaku sehingga hal tersebut diharapkan akan ada yang bertanggung jawab terhadap korban dan masa depannya. Kita tahu bahwa Prinsip ini mengedepankan perdamaian dengan memperhatikan masa depan korban dan pelaku. Model ini merupakan salah satu bentuk penyelesaian hukum di luar pengadilan". 7

Hasil wawancara dengan Aiptu Endang Iswarini, S.H., Kepala Unit Perlindungan Perempuan dan Anak (PPA) Kepolisian Resort (Polres) Purbalingga, pada hari Selasa tanggal 19 Januari 2016.

Hasil wawancara dengan Suyatno, Kepala Pusat Pelayanan Terpadu Perlindungan Perempuan dan Anak 


\begin{abstract}
Berdasarkan hasil
wawancara dengan pelaku

anak $(\mathrm{Al}), \quad$ diperoleh

keterangan bahwa:

"Saya tidak tahu perbuatan yang saya lakukan kepada korban itu perbuatan apa. Lha wong saya cuman disuruh main kawin-kawinan, ya saya jadi melakukan itu karena dipaksa oleh teman. Saya cuman pengin tahu dan nyoba kawin itu kayak gimana". 8

Sedangkan pelaku anak lainnya (Ra), memberikan keterangan bahwa:
\end{abstract}

"Saya tidak tahu kawin itu apaan kan. Nah saya hanya ngikutin yang diajarin sama temen saya. Temen saya itu ngomong kalau kawin itu enak, terus dia ngajarin saya buat buka baju, buka celana juga, terus dia kasih contoh gituan". 9

Korban anak (So) mengakui bahwa:

“Dia (pelaku) melakukan itu kepada saya (korban) itu pas siang-siang hari pas sepi.

(P2TP2A) Kabupaten Banjarnegara, pada hari Senin tanggal 21 Desember 2015.

8 Hasil wawancara dengan Al (nama disamarkan), pelaku tindak pidana kekerasan seksual.

9 Hasil wawancara dengan Ra (nama disamarkan), pelaku tindak pidana kekerasan seksual.
Katanya dia abis diceritai sama temennya, nah terus dia buka bajunya di depanku dan menyuruh aku juga buat buka baju terus masukin alat kelamin sama-sama”. ${ }^{10}$

Lain halnya dengan pelaku tersebut, korban lain (An) menyatakan bahwa:

"Pelaku melakukan itu kepada saya setelah dia melihat temannya memasukan itunya. Dia bilangnya kaya gitu ke saya, ya terus dia meniru kaya gitu kepada saya karena temannya bilang rasanya enak makannya pelaku kayak gitu ke saya". ${ }^{11}$

Menurut Kepala

Pusat Pelayanan Terpadu Perlindungan Perempuan dan Anak (P2TP2A) Kabupaten Banjarnegara penanganan tindak pidana kekerasan seksual yang dilakukan oleh pelaku anak belum dapat dilakukan secara maksimal, sebab:

"Dalam hal perlindungan terhadap korban kekerasan seksual yang dilakukan oleh pelaku anak, belum

10 Hasil wawancara dengan So (nama disamarkan), korban tindak pidana kekerasan seksual.

11 Hasil wawancara dengan An (nama disamarkan), korban tindak pidana kekerasan seksual. 
665 | Jurnal Idea Hukum

Vol. 3 No. 2 Oktober 2017

Magister Hukum Fakultas Hukum Universitas Jenderal Soedirman

$\begin{array}{lr}\text { terjangkau } & \begin{array}{r}\text { secara } \\ \text { keseluruhan } \\ \text { banyaknya kasus kekerasan }\end{array} \\ \text { seksual yang dilakukan oleh } \\ \text { pelaku anak di } \text { Kabupaten } \\ \text { Banjarnegara, sedangkan } \\ \text { anggaran untuk menangani } \\ \text { kasus kekerasan seksual } \\ \text { yang dilakukan oleh pelaku } \\ \text { anak sedikit". } 12\end{array}$

Menurut Penyidik

dalam satuan unit

Perlindungan Perempuan

dan Anak (PPA) Kepolisian

Resort

(Polres)

Banjarnegara, perdamaian antara pelaku dan korban

didampingi oleh keluarga dan

tokoh masyarakat setempat, yaitu:

“Demi melihat kepentingan

umum yang menurut masyarakat masih dapat didamaikan maka akan diberi kesempatan kepada para pihak untuk melakukan perdamaian. Pelapor dan terlapor tetap akan diperiksa dan memberikan waktu untuk berdamai. Dalam hal sedang berlangsungnya proses perdamaian yang melibatkan pelaku dan orang tua pelaku, korban dan orang tua

12 Hasil wawancara dengan Suyatno, Kepala Pusat Pelayanan Terpadu Perlindungan Perempuan dan Anak (P2TP2A) Kabupaten Banjarnegara, pada hari Senin tanggal 21 Desember 2015. korban, serta masyarakat, kepolisian bertugas sebagai pemantau agar proses perdamaian dapat terjadi secara leluasa. Apabila telah terjadi kesepakatan di antara para pihak, maka hasil perdamaian akan dilaporkan kembali ke Polres untuk kemudian dilakukan pengecekan kepada semua pihak mengenai kesepakatan perdamaian agar terhindar dari pemaksaan. Setelah itu, dibuatlah surat pernyataan perdamaian yang kemudian akan dilaporkan kepada atasan untuk selanjutnya agar melakukan penghentian penyidikan". ${ }^{13}$

Tindakan

menerapkan restorative justice juga dilakukan oleh Kepolisian Resort (Polres) Purbalingga. Menurut Kepala Unit Perlindungan Perempuan dan Anak (PPA) Kepolisian Resort (Polres) Purbalingga, penerapannya yaitu:

"Tersangka dalam perkara anak tidak ditahan dengan pertimbangan bahwa Kepolisian Resort (Polres)

Hasil wawancara dengan Bripka Deberti Selfiana Doko, Penyidik Satuan Unit Perlindungan Perempuan dan Anak (PPA) Kepolisian Resort (Polres) Banjarnegara, pada hari Rabu tanggal 30 September 2015. 


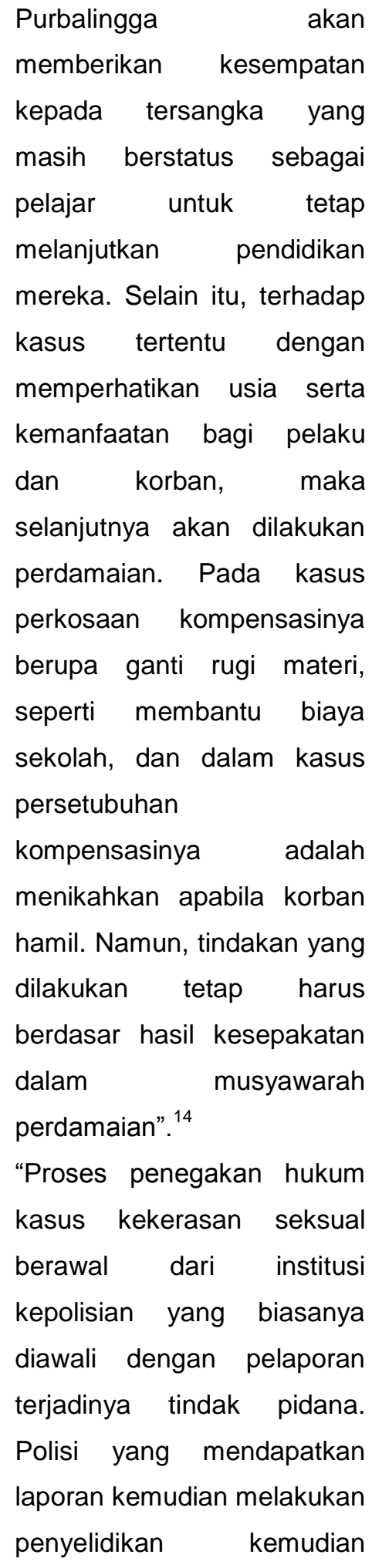

$14 \quad$ Hasil wawancara dengan Aiptu Endang Iswarini, S.H., Kepala Unit Perlindungan Perempuan dan Anak (PPA) Kepolisian Resort (Polres) Purbalingga, pada hari Selasa tanggal 19 Januari 2016. penyidikan atau tidak. Proses penegakan hukum di Polres terdapat suatu kemudahan dalam proses pelaporan sampai dengan proses penyidikan. Berawal dari proses pelaporan yaitu tahap awal datang ke Sentra Pelayanan Kepolisian (SPK) kemudian diarahkan ke unit Perlindungan Perempuan dan Anak (PPA) untuk selanjutnya dilakukan proses visum dan pengumpulan barang bukti. Pelaporan tersebut tidak membutuhkan persyaratan yang perlu disiapkan secara khusus. Korban bisa langsung datang karena semua terkait yang diperlukan dalam pelaporan penyidik sendiri yang akan mempersiapkan". ${ }^{15}$

Kepala Kepala Biro Operasional (KBO), Kepolisian Resort (Polres) Purbalingga juga menyatakan bahwa:

"Terhadap kasus yang sudah masuk tidak ada penundaan dan biasanya langsung diproses sebagaimana mestinya yaitu pada prinsipnya pada saat korban melapor, pada waktu itu juga

Hasil wawancara dengan Setiadji, Kepala Kepala Biro Operasional (KBO), Kepolisian Resort (Polres) Purbalingga, pada hari Selasa tanggal 26 Januari 2016. 
667| Jurnal Idea Hukum

Vol. 3 No. 2 Oktober 2017

Magister Hukum Fakultas Hukum Universitas Jenderal Soedirman

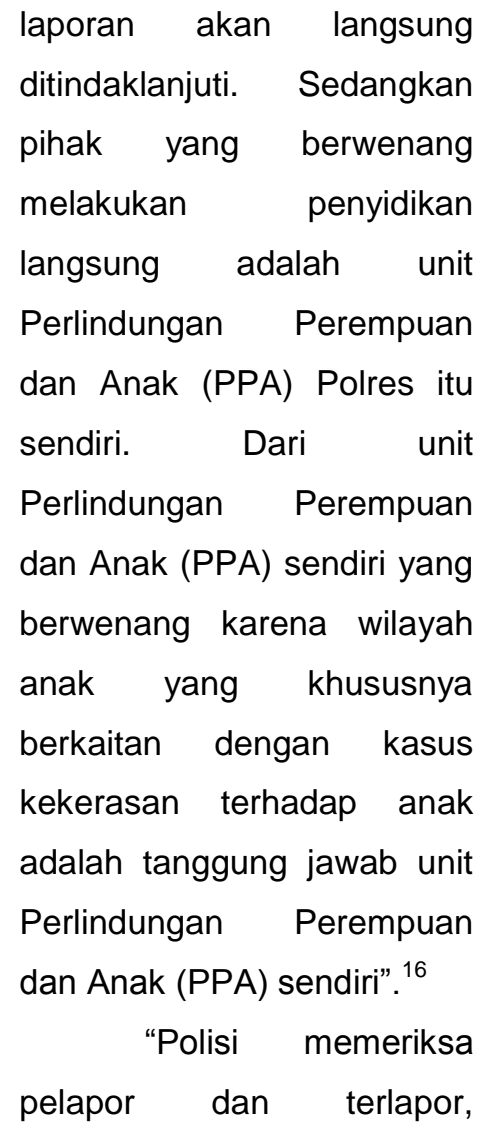

kemudian memberikan waktu

untuk melakukan mediasi

setelah berkoordinasi

dengan pelaku, korban,

keluarga, dan masyarakat.

Ketika proses musyawarah,

polisi sebagai pihak

pemantau untuk memberi

keleluasaan kepada para

pihak. Setelah terjadi kesepakatan, semua pihak

tentunya akan melapor

kembali ke Polres, untuk

selanjutnya polisi melakukan

pengecekan kepada semua

pihak mengenai kesepakatan

mereka, hal tersebut

dilakukan untuk menghindari adanya pemaksaan. Jika

dianggap sudah cukup,

kemudian akan ada surat

pernyataan perdamaian

untuk selanjutnya dilaporkan

kepada atasan untuk

melakukan penghentian

penyidikan". ${ }^{17}$

\section{Data Sekunder:}

1. UU Kesejahteraan Anak

2. UU Pengadilan Anak

3. UU Polri

4. UU Sistem Peradilan

Pidana Anak

5. UU Perlindungan Anak

6. KUHP

b. Hambatan-hambatan yang Dihadapi dalam Penerapan Prinsip Restorative Justice untuk Menyelesaikan Tindak Pidana Kekerasan Seksual yang Dilakukan oleh Pelaku Anak

Data Primer

Dalam hal hambatan yang dihadapi oleh Kepolisian Resort (Polres) Banjarnegara seperti yang dinyatakan oleh Bripka Deberti Selfiana Doko, Penyidik Satuan Unit Perlindungan Perempuan

Hasil wawancara dengan Yunis, Anggota Unit Perlindungan Perempuan dan Anak (PPA) Kepolisian Resort (Polres) Purbalingga, pada hari Selasa tanggal 26 Januari 2016. 
dan Anak (PPA) Kepolisian

Resort

(Polres)

Banjarnegara, yaitu:

"Dalam

menerapkan

restorative justice terdapat

kendala yaitu seperti

pemahaman terhadap

restorative justice yang

belum menyeluruh seperti

halnya pelibatan pelaku dan

korban, persamaan dalam

pencapaian proses

penyelesaian dan upaya

pencapaian penyelesaian

yang mendasarkan pada

restorative justice yang harus

mengacu kepada kebutuhan

pelaku, korban, dan

masyarakat untuk

memperbaiki hubungan

sosial. Selain itu, korban sulit

berdamai dengan alasan

perbuatan yang dilakukan

oleh pelaku sangat

merugikan korban". ${ }^{18}$

Sedangkan

hambatan yang dihadapi

oleh Kepolisian Resort

(Polres) Purbalingga menurut

Aiptu Endang Iswarini, S.H.,

Kepala Unit Perlindungan

Perempuan dan Anak (PPA)

Kepolisian Resort (Polres)

Purbalingga dalam

18 Hasil wawancara dengan Bripka Deberti Selfiana Doko, Penyidik Satuan Unit Perlindungan Perempuan dan Anak (PPA) Kepolisian Resort (Polres) Banjarnegara, pada hari Senin tanggal 21 Desember 2015.

\begin{abstract}
menerapkan restorative
justice adalah dari segi

tujuan pemidanaannya.
\end{abstract}

"Dengan penerapan

restorative justice diragukan

bahwa pelaku tindak pidana

akan jera yang kemudian

menjadikan perlindungan

masyarakat dan pelaku akan

terwujud. Selain itu akan

muncul anggapan bahwa

anak-anak yang melakukan

tindak pidana tidak akan

dipidana karena diterapkan

restorative justice. Terlebih

lagi, belum semua kasus

dapat diterapkan

penyelesaian dengan

restorative justice karena

adanya perbedaan persepsi

dalam masyarakat yang

menyatakan bahwa orang

yang bersalah harus

dihukum. Begitupun persepsi

para pihak, baik pelaku

maupun korban sehingga

korban tidak mau berdamai.

Hambatan lainnya dapat

dilihat dari segi tujuan

pemidaan yang kurang

tercapai". ${ }^{19}$

19 Hasil wawancara dengan Aiptu Endang Iswarini, S.H., Kepala Unit Perlindungan Perempuan dan Anak (PPA) Kepolisian Resort (Polres) Purbalingga, pada hari Selasa tanggal 26 Januari 2016. 


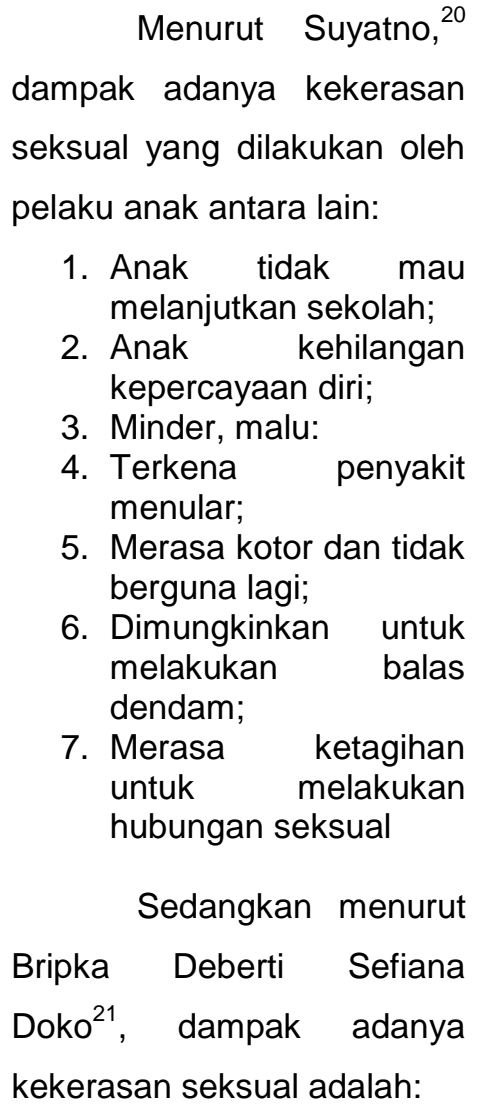

1. Anak tidak mau melanjutkan sekolah;

2. Anak kehilangan kepercayaan diri;

3. Minder, malu:

4. Terkena penyakit menular;

5. Merasa kotor dan tidak berguna lagi;

6. Dimungkinkan untuk melakukan balas dendam;

7. Merasa ketagihan untuk melakukan hubungan seksual

Sedangkan menurut

Bripka Deberti Sefiana Doko $^{21}$, dampak adanya kekerasan seksual adalah:

1. Anak menjadi stres bahkan dimungkinkan mengalami gangguan jiwa baik ringan maupun berat;

2. Adanya luka-luka;

3. Anak akan kehilangan keperawanan;

4. Anak bisa takut kepada laki-laki;

5. Masa depan anak yang kurang baik;

6. Sulit mencari jodoh karena anak sudah tidak perawan;

7. Hamil di luar nikah;

8. Merasa dirinya kotor;

9. Merasa bersalah yang tidak kunjung usai.

20 Kepala Pusat Pelayanan Terpadu Perlindungan Perempuan dan Anak (P2TP2A) Kabupaten Banjarnegara.

21 Penyidik Satuan Unit Perlindungan Perempuan dan Anak (PPA) Kepolisian Resort (Polres) Banjarnegara. 
teman-teman dan

pergaulan sehari-hari.

\section{Data Sekunder:}

UU Perlindungan Anak

\section{Pembahasan}

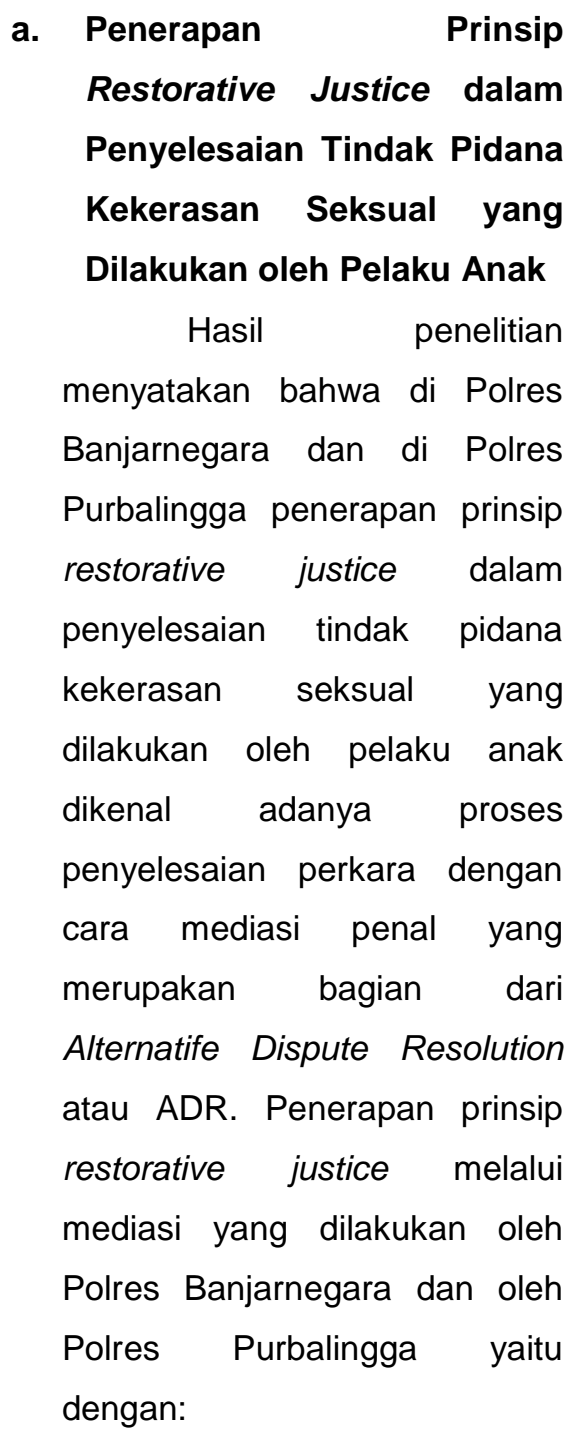

1. Proses

perdamaian;

2. Penghentian

penyidikan

karena dicapainya

kesepakatan;

3. Memberi bantuan biaya sekolah pada korban dalam

kasus perkosaan;

4. Tidak menahan pelaku anak;

5. Tetap melakukan penetapan tersangka;

6. Mempertimbangka n aspek tertentu untuk mediasi;

7. Menikahkan korban dengan pelaku (dinikahkan terutama pada kasus persetubuhan, yaitu apabila korban hamil);

8. Menitikberatkan ganti rugi pada korban;

9. Melakukan proses hukum namun tetap melindungi anak;

10. Penyelesaian perkara secara mediasi adat kekeluargaan.

b. Hambatan-hambatan yang Dihadapi dalam Penerapan Prinsip Restorative Justice untuk Menyelesaikan Tindak Pidana Kekerasan Seksual yang Dilakukan oleh Pelaku Anak

Hambatan-hambatan

yang dialami oleh Kepolisian 
671 | Jurnal Idea Hukum

Vol. 3 No. 2 Oktober 2017

Magister Hukum Fakultas Hukum Universitas Jenderal Soedirman

Resort (Polres) Banjarnegara

maupun oleh Kepolisian Resort

(Polres) Purbalingga dalam

menyelesaikan tindak pidana

kekerasan seksual yang

dilakukan oleh pelaku anak

antara lain adalah berkaitan

dengan rumusan hukum atau

substansi,

persoalan

kelembagaan atau strukturnya, dan persoalan kultur atau

budaya yang hidup dan

berkembang di dalam

masyarakat. Hal tersebut

bersesuaian dengan Teori

Lawrence M. Friedman

mengenai tiga unsur sistem

hukum yaitu Struktur Hukum

mengenai aparat penegak

hukum, Substansi Hukum

mengenai peraturan perundangundangan, dan Kultur Hukum

atau budaya hukum yaitu

pandangan yang hidup dan

berkembang di dalam

masyarakat.

Hambatan yang dialami

oleh Polres Banjarnegara dan

oleh Polres Purbalingga dalam menyelesaikan tindak pidana

kekerasan seksual yang

dilakukan oleh pelaku anak

berkaitan dengan:

1. Rumusan hukum atau substansi;

2. Persoalan

kelembagaan atau strukturnya; dan
3. Persoalan kultur atau budaya yang hidup dan berkembang di dalam masyarakat.

Hal-hal tersebut terkait keilmuan yang dimiliki aparat penegak hukum dan pengetahuan masyarakat tentang penerapan prinsip restorative justice. Berdasarkan aspek tersebut, hambatan yang dialami antara lain:

1. Jumlah polwan yang masih sangat minim

2. Pemahaman gender yang belum memadai

3. Kurangnya pemahaman hukum ditambah tidak tahu aturan tentang kekerasan seksual yang dilakukan oleh anak

4. Pemahaman prinsip restorative justice belum mendalam

5. Berbagai peraturan tentang anak masih tumpang tindih, belum adanya norma yang menjamin kesaaman tindakan 
6. Penerapan

$$
\begin{array}{lr}
\text { restorative } & \text { justice } \\
\text { dianggap tidak } \\
\text { membuat pelaku } \\
\text { jera dan } \\
\text { dimungkinkan } \\
\text { mengulangi } \\
\text { perbuatan }
\end{array}
$$

7. belum semua

kasus dapat

diselesaikan

dengan

restorative

justice karena

ada anggapan

orang salah

harus

dihukum.

\section{PENUTUP}

\section{Simpulan}

Berdasarkan hasil penelitian dan pembahasan yang telah diuaraikan, maka dapat disimpulkan bahwa:

1. Penerapkan prinsip restorative justice dalam penyelesaian tindak pidana kekerasan seksual yang dilakukan oleh pelaku anak dilakukan oleh penyidik Polri melalui kewenangan diskresi yaitu seperti yang dinyatakan di dalam Pasal 18 Undang-undang Nomor 2 Tahun 2002 tentang Polisi Republik Indonesia.

Di Polres Banjarnegara maupun di Polres Purbalingga, penerapan prinsip restorative justice dalam penyelesaian tindak pidana kekerasan seksual yang dilakukan oleh pelaku anak dikenal adanya proses penyelesaian perkara melalui mediasi. Penerapan prinsip restorative justice dengan cara mediasi penal yang dilakukan oleh Polres Banjarnegara dan oleh Polres Purbalingga tersebut merupakan bagian dari Alternatife Dispute Resolution atau ADR yang antara lain melalui proses perdamaian, penghentian penyidikan karena dicapainya kesepakatan, memberi bantuan biaya sekolah pada korban dalam kasus perkosaan, tidak menahan pelaku anak, tetap melakukan penetapan tersangka, mempertimbangkan aspek tertentu untuk mediasi, menikahkan korban dengan pelaku (dinikahkan terutama pada kasus persetubuhan, yaitu apabila korban hamil), menitikberatkan ganti rugi pada korban, melakukan proses hukum namun tetap melindungi anak, penyelesaian perkara 
Magister Hukum Fakultas Hukum Universitas Jenderal Soedirman

secara mediasi adat

kekeluargaan.

2. Hambatan yang dialami oleh Kepolisian Resort

(Polres) Banjarnegara maupun oleh Kepolisian Resort (Polres) Purbalingga dalam menyelesaikan tindak pidana kekerasan seksual yang dilakukan oleh pelaku anak antara lain berkaitan dengan rumusan hukum atau substansi, persoalan kelembagaan atau strukturnya, dan persoalan kultur atau budaya yang hidup dan berkembang di dalam masyarakat. Hal tersebut terkait keilmuan yang dimiliki aparat penegak hukum dan pengetahuan masyarakat tentang penerapan prinsip restorative justice.

\section{Saran}

Beberapa saran berkaitan dengan permasalahan yang diajukan dalam penelitian ini antara lain:

1. Restorative justice seharusnya diterapkan sebagai salah satu jenis sanksi pokok untuk anak khususnya dalam tindak pidana kekerasan seskual yang dilakukan oleh pelaku anak dan bukan sebagai jenis alternatif cara penyelesaian perkara yang

melibatkan anak. Hal tersebut bertujuan mencari penyelesaian yang adil yang menekankan pemulihan kembali pada keadaan semula dan bukan pada pembalasan. Oleh karena itu, diperlukan peraturan khusus yang mengatur tentang penerapan prinsip restorative justice agar tidak terjadi tumpang tindih sehingga prinsip restorative justice secara resmi dapat diterapkan dalam penyelesaian tindak pidana kekerasan seskual yang dilakukan oleh pelaku anak agar dapat menjamin kesamaan tindakan penyidik Polri dalam penerapan prinsip restorative justice.

2. Kepolisian Resort (Polres) Banjarnegara maupun Kepolisian Resort (Polres) Purbalingga seharusnya mulai mensosialisasikan Undang-undang Nomor 11 Tahun 2012 tentang Sistem Peradilan Pidana Anak yang mengatur mengenai penyelesaian perkara menggunakan prinsip restorative justice agar pandangan masyarakat mengenai pembalasan 


\begin{abstract}
melalui proses penjara beralih kepada pemulihan melalui proses perdamaian. Profesionalitas kerja aparat penegak hukum juga dituntut harus selalu siap dengan pemahaman yang mendalam terhadap prinsip beserta penerapannya sehinga dalam proses penerapan restorative justice dalam suatu perkara dapat memberi manfaat yang terbaik bagi anak dan sesuai dengan tujuan pemidanaan.
\end{abstract}

\section{DAFTAR PUSTAKA}

\section{Buku}

Gosita, Arif. 2009. Victimology, Prespektif Korban dalam Penanggulangan Kejahatan, Yogyakarta: Universitas Atma Jaya;

M. Friedman, Lawrence. 1975. The Legal System, A Social Science Perspective. New York: Russel Sage Foundation;

Marlina. 2010. Pengantar Konsep Diversi dan Restorative Justice dalam Hukum Pidana. Medan: USU Press;

Prasetyo, Teguh dan Abdul Halim Barkatullah. 2005. Politik Hukum Pidana Kajian Kebijakan Kriminalisasi dan Dekriminalisasi. Yogyakarta: Pustaka Pelajar;

Rahardjo, Satjipto. Tanpa Tahun. Masalah Penegakan Hukum, Suatu Tinjauan Sosiologis. Bandung: Sinar Baru;

--------. 2009. Penegakan Hukum, Suatu Tinjauan Sosiologis. Yogyakarta: Genta Publishing;

Reksodiputro, Mardjono. 1994. Partisipasi Profesi Hukum sebagai Penegak Hukum dalam Peningkatan Wibawa Penagakan Hukum dalam Hak Asasi Manusia dalam Sistem Peradilan Pidana. Jakarta: Pusat Pelayanan Keadilan dan Pengabdian Hukum Universitas Indonesia;

Salman, Otje. 2010. Filsafat Hukum (Perkembangan dan Dinamika Masalah). Bandung: Refika Aditama;

Sari Putra, Bhineka Teruna. 2013. Penerapan Restorative Justice dalam Penanganan Tindak Pidana yang dilakukan oleh Anak (Studi di Wilayah Hukum Kepolisian Resort Purbalingga). Tesis. Fakultas Hukum Universitas Jenderal Soedirman Purwokerto;

Soekanto, Soerjono. 1983. Faktor-faktor yang Mempengaruhi Hukum. Jakarta: Rajagrafindopersada;

Sudarto. 1986. Kapita Selekta Hukum Pidana. Bandung: Alumni;

Susanto, Anthon. 2004. Wajah Peradilan Kita. Bandung: Refika Aditama;

Wahid, Eriyantouw. 2009. Keadilan Restoratif dan Peradilan Konvensional dalam Hukum Pidana. Jakarta: Universitas Trisakti;

Wahyudi, Setya. 2011. Implementasi Ide Diversi dalam Pembaharuan Sistem Peradilan Pidana Anak di Indonesia. Yogyakarta: Genta Publishing;

Warassih, Esmi. 2005. Pranata Hukum Sebuah Telaah Sosiologis. Semarang: Suryandaru Utama.

Priyanto, Dwidja. 2007. Pemidanaan untuk Anak dalam Konsep Rancangan KUHP (dalam Kerangka Restorative Justice). Bandung: Lembaga Advokasi Hak Anak (LAHA), Edisi VIII/Volume III;

Banyumas1. Tim Harapan Purbalingga Tangani 24 Kasus KDRT. http://banyumasnews.com/9469/ti $\mathrm{m}$-harapan-purbalingga-tangani24-kasus-kdrt/. Diakses pada tanggal 2 Desember 2015;

Ray Pratama Siadari. Pengertian, Jenisjenis, dan Tujuan Pemidanaan. http://raypratama.blogspot.com/20 12/02/pengertian-jenis-jenis-dantujuan.html. Diakses pada tanggal 11 September 2015; 
675 | Jurnal Idea Hukum

Vol. 3 No. 2 Oktober 2017

Magister Hukum Fakultas Hukum Universitas Jenderal Soedirman

Soetanto Soepiadhy. Bekerjanya Hukum dalam Masyarakat. http://surabayapagi.com/. Diakses pada tanggal 8 Oktober 2015.

Wahyu Tanoto. Kekerasan Seksual di Banjarnegara.

http://m.kompasiana.com/cupitu7 grafi/kekerasan-seksualdibanjarnegara. Diakses pada tanggal 2 Desember 2015. 